\title{
Examining the Performance Level of Project Management Competencies of Architects in Ghana Using Gap Analysis Approach
}

\author{
*Titus Ebenezer Kwofie, Edward Ayebeng Botchway and \\ Samuel Amos-Abanyie
}

\begin{abstract}
Published online: 31 August 2018
To cite this article: Titus Ebenezer Kwofie, Edward Ayebeng Botchway and Samuel Amos-Abanyie (2018). Examining the performance level of project management competencies of architects in Ghana using gap analysis approach. Journal of
\end{abstract} Construction in Developing Countries, 23(1): 125-147. https://doi.org/10.21315/jcdc2018.23.1.8.

To link to this article: https://doi.org/10.21315/jcdc2018.23.1.8

\begin{abstract}
Evaluation of the performance level of key project management (PM) competencies of the various project teams is perceived as a recourse necessary for identifying potentially crucial and practical training needs of project team participants in PM practice. However, notable studies in this domain have primarily focused on the identification of critical PM competencies of project managers and engineers of the project team neglecting the architect who are equally important participants of construction project teams. This study focused on assessing the performance level of the critical PM competencies of the architect as a key team participant in project delivery. A quantitative method design was adopted involving a structured questionnaire survey of Ghanaian construction professionals who were selected through snow balling sampling. The data elicited were analysed using mean scores, Kruskal-Wallis test and gap analysis. The findings revealed that, architects show worse performance on seven critical competencies. The practical implication of the findings is that the disposition of architects PM behaviours can be ascertained as this can lend credence to legitimising corrective action through any potential continuing professional development programme and training in PM for architects in the Ghanaian construction industry.
\end{abstract}

Keywords: Project management, Project management competencies, Architects, Continuing professional development

\section{INTRODUCTION}

The global increase in certification, adoption and training in project management (PM) practices give credence to its acceptance as a sure management paradigm that enhances project delivery. Currently in the world, it can be said that PM is becoming global and has received extension beyond traditional application as seen in the increased demand for the project managers and PM practices in several sectors of the global economy (Project Management Institute [PMI], 2008; Crawford, 1998; 2005). In the context of ensuring an acceptable level of performance towards PM success, several studies have demanded the need for the application of globally consistent, generic standards and practices among the project teams (Stanleigh, 2010; Ahadzie et al., 2009; Crawford, 2005; 1998). However, there is an empirical indication that project team participants tend to struggle in coping with the needed level of job and task performance in their

Department of Architecture, Kwame Nkrumah University of Science and Technology, Kumasi, GHANA "Corresponding author: tekwofie.cap@knust.edu.gh 
project roles and management capabilities (Stanleigh, 2010; Ahadzie et al., 2009). This development tends to affect the ability of project team participants to perform and deal effectively with their broader mandate of creating a PM culture within the organisation that are necessary to engendering the expected performance outcome (Stanleigh, 2010; Enshassi, Mohamed and Abushaban, 2009). Notably, project team participants perform at the task level that do not demonstrate a clear understanding of the full scope of their role responsibilities on a project within a PM based environment (Skipper and Bell, 2008). This often leads to managerial inefficiencies, team ineffectiveness and project failures (Enshassi, Mohamed and Abushaban, 2009).

Given that project teams evolved from different specialist background into an intensive interdependent, collaborative, multi-disciplinary project based environment, it is affirmed that, successful delivery of projects in PM based organisations requires that the project team participants possess and demonstrate proficiency in PM knowledge and skills alongside their technical job roles (Omidvar, Samad and Zafarghandi, 2011 ; Stanleigh, 2010; Skipper and Bell, 2008).

Pellegrinelli and Bowman (1994) and Adams and Thomas (1991) emphasised that, the process of modifying organisations to be able to precipitate strategic gains and enhanced performance outcome necessitates the provision of concentrated management attention delivered only by competent, committed, well-organised, knowledgeable and skilled project teams. This however makes the assertion that, the project manager is solely responsible for the success or failure of a project not wholly still valid but rather a collective responsibility of the project team participants. Against this background, it is crucial that all project team participants develop their PM competencies to be able to engender the needed effort towards expected performance outcome that is suitable to stimulate the needed delivery success. Unfortunately, given the growing level of acceptance and adoption of PM practices in the Ghanaian Construction Industry (GCl) and global level, the industry continues to struggle in performance and saddled with managerial inefficiencies and ineffectiveness across all the phases of the construction process (Ahadzie and Amoa-Mensa, 2010; Ahadzie et al., 2009; Ogunsemi, Oyediran and Ekundayo, 2008). This is evidenced in the prevalent occurrence of frequent delays on construction projects (Buertey, Miezah and Adjei-Kumi, 2013; Danso and Fugar, 2009). However, several studies on the industry in Ghana have explored various means of generating the needed improvement (see Danso and Fugar, 2009; Ahadzie et al., 2009). Consequently, studies by Buertey, Miezah and Adjei-Kumi (2013) and Ahadzie and Amoa-Mensah (2010) have identified the development and adoption of efficient PM practices in the industry as key towards engendering the needed managerial improvement. They emphasised that, this can be achieved by continuously assessing, identifying and developing the key PM competencies needed for superior performance in the industry among all the project team participants. In spite of this assertion, studies on the PM competencies of the project teams have focused primarily on the project manager and in some situations, the engineer (Ahadzie, Proverbs and Sarkodie-Poku, 2014; Bothma, 2012; Ahadzie et al., 2009). In the industry in recent times, it can be said that, practically, architects and quantity surveyors professionals have traditionally played leadership roles on project teams and often replaced project managers on projects where the PM concept has been adopted (Yadollahi et al., 2014).

A critique of previous studies reveal that the primary focus has been on the identification of key PM competencies across the project team neglecting the 
evaluation of how project team participants perform on these critical PM skills (see Dainty, Cheng and Moore, 2004; Ahadzie et al., 2009; Bothma, 2009; Kwofie, Adinyira and Botchway, 2015). The main aim of this study was to assess the performance level of architects' critical PM competencies in order to engender their training and development to inform their acceptable level of contribution to management practices in project teams towards delivery success. The findings of the study is thus very necessary towards providing the basis for continuous professional development and training of architects and other project team participants that are crucial towards performance based assessment, job design and selection of project personnel for improved project performance.

\section{LITERATURE REVIEW}

\section{Theoretical Perspective of PM Performance and Success}

The theoretical underpinning of PM success lies in the foundation that, when project teams retain and demonstrate acceptable level of performance on the requisite PM competency behaviours in their project delivery roles, can elicit acceptable performance outcome towards project success, team effectiveness, managerial efficiency (Crawford, 2005; 1998; Dainty, Cheng and Moore, 2004). Chinowsky, Diekman and Galoti (2008) argued that the success of construction and engineering projects depend on two fundamental elements of effective management of the technical component of tasks and ability of project participants to effectively develop into high performance team. Xiong et al. (2013) also demonstrated that, performance of project participants is critical to project success as well as enhancing the satisfaction of participants and improving their motivation and cooperation.

Similarly, Masrom, Skitmore and Bridge (2013) intimated that objective and subjective attributes of performance measurements are extremely crucial if the need to overcome the challenges of construction industry performance. In the arguments of Xiong et al. (2013) and Masrom, Skitmore and Bridge (2013), project team participants performance are panacea for both project success and client and team satisfaction.

Historically, several studies have acknowledged that, the achievement of this is highly dependent on the project team developing key PM skills that significantly impact on management of tasks, resources, planning and performance and offer a strategic realisation of goals (see Ogunsemi, Oyediran and Ekundayo, 2008; Chinowsky et al., 2008; Crawford, 1998; Pellegrinelli and Bowman, 1994; Adams and Thomas, 1991). Ogunsemi, Oyediran and Ekundayo (2008) have empirically proven that, all project team participants (project manager, architect, quantity surveyor, structural engineer, electrical engineer, plumbing and mechanical engineer, etc.) require various forms of PM skills depending on their roles, extent of involvement and the phase of the project life-cycle to be able to prompt the needed PM success. Further, it is argued that, an acceptable level of performance from all participants on their various PM competencies is crucial towards PM success. However, the palpable development among project teams is the lack of knowledge and understanding of their performance level on their PM skills in project delivery (Fayek, 2012).

The theoretical antecedent of developing competent team towards PM success is that, in the industry today, stakeholders and researchers have recognised 
a paradigm shift from the traditional individual PM competencies (only the project manager) to all project team competencies in PM to archive organisational competence (Omar and Fayek, 2016; Brown, 2000; Pellegrinelli and Bowman, 1994). This is premised on the fact that, team or organisational competence gives superior performance and rewards for management success and performance (Gillies and Harris, 2009; Omar and Fayek, 2016). To this end, Draganidis, Chamopoulou and Mentzas (2006) contended that, in work groups and teams, individual competencies of the team participants remain the fundamental building blocks of organisational team competency and thus seen as very crucial in impacting the performance outcome of the team towards project success. In the light of this, the knowledge put forward is that, in any work groups or team performing a task, it is more likely the same set of contextual and professional competencies normally cuts across jobs related to the approach of the task. Hence these competencies can be identified and analysed to determine their acceptable levels of performance on the task necessary to meet expected outcome by the group (Sanchez and Levine, 2009).

\section{The Case of the Architects' PM Competencies and Performance Levels}

It has been argued that PM competencies among project teams are considered as an impetus for team performance and delivery success. However, it has become clear that generic PM competencies across all team professionals is lacking theoretical rigour and ineffective. This is because, all team professionals perform varying tasks and functions across the different project life cycle phases and thus will require different PM skills that are commensurate to their tasks and functions (Ogunsemi, Oyediran and Ekundayo, 2008; Rwelamila, 2007; Odusami and lyagba, 2001; Edum-Fotwe and McCaffer, 2000). The theoretical and practical significance of essential PM credentials across all project team participants are not only for ensuring success and enhancing team integration but also for sound management of stakeholder goals and triune performance of tasks. However, notable studies have tended to focus on project managers, engineers and quantity surveyors (Bothma, 2012; Omidvar, Samad and Zafarghandi, 2011; Ogunsemi, Oyediran and Ekundayo, 2008; Zavadskas et al., 2008). Traditionally, all the professionals that constitute the project team (architects, civil, structural, mechanical and electrical engineers and quantity surveyors) perform both task functional and managerial important roles irrespective of the management approach adopted in the delivery of the construction projects and the roles are crucial towards the attainment of the project goals.

Oyedele et al. (2003) empirically attested that, PM practice has become an integral part of architecture practice in most developing countries. Inspite of this observation and development affirmed by Oyedele et al. (2003), it can be attested that, practically, PM penetration in the construction industry in respect of architectural consulting practice at the infantry stage. Against this, demonstrating some level of PM skills is critical to the success of architects in deliverying high tasks performance in project delivery across all the project life cycle phases (Odusami, 2002). In the Ghanaian construction industry setting, architects have traditionally played the role as project team leaders and often are entrusted with the functional role and authority which is often of the same level as that of project managers in of PM practice (Ahadzie, Proverbs and Sarkodie-Poku, 2014). Likewise, Yadollahi et al. (2014) also empirically acknowledged that, among the various project team professionals, architects are frequently appointed as a project manager and project leader in many developing countries and thus the capability of an architect 
in PM and leadership role is critical in reducing challenges encountered in project delivery. These assertions affirm the significance of architects' understanding of the PM concept, their knowledge of the needed critical PM skills as well as their performance level towards engendering effective management and enhanced performance in the task function. In the opinion of Xia et al. (2015), design quality significantly impact on project performance and the effectiveness of communication. Given the centrality of architects in the design process in project delivery, it is important to ensure an acceptable performance in their design roles and functions.

Yadollahi et al. (2014) and Omar and Fayek (2016) looked at improving PM performance and success in construction project delivery and both acknowledged that, PM philosophies, processes, methods, tools and effective design management are critical important factors that can influence successful management of a construction projects. In recent times, effective design management has emerged as an important management technique which has been encouraged as a result of the growing complexities of building process relating to the functional and technical requirements (Oyedele et al., 2003; Koskela, Huovila and Leinonen, 2002). Certainly with these complexities come with its consequent managerial challenges and professional pressure which traditional project managers are not adequately primed and equipped managerially to deal with the modern design challenges compared to architects (Gray and Hughes, 2012). Likewise, Koskela, Huovila and Leinonen (2002) also indicated that, management of construction project design has often been poorly carried out due to lack of application of appropriate sound and managerial approaches in the delivery of construction projects.

Furthermore, themodelforselecting architects by projectmanagers developed by Ling (2003) proved that sound knowledge and acceptable performance level in the management approach adopted on a construction projects by architects are critical for better control of the design and management of the project. Against this, it can be argued that architects developing and performing effectively on key managerial competencies could be ascribed as very significant towards PM success in construction project delivery. This is because the authority and role of architects across all the phases of the project life cycle of construction projects is a well acknowledged and recognised trend within the professional hierarchy in both traditional and PM approaches. The most dominant professional PM institution have developed various but similar in scope and content generic competency models that are fundamental towards the knowledge and skills (competencies) development in PM practice. These competency profile models significantly stress that, three main parameters of knowledge and skills in PM competency are critical among project teams (Omidvar, Samad and Zafarghandi, 2011; Crawford, 2005; Edum-Fotwe and McCaffer, 2000). This was further corroborated by Odusami (2002) on developing important skills for project team leaders and team participants. The three parameters indicate competences that relate to technical (job), behavioural and contextual aspects in PM (Omidvar, Samad and Zafarghandi, 2011). The technical PM tasks and functional competencies relate the core job function standard to be achieved whereas the behavioural or personal competencies refers to the personal characteristics, the management skills and knowledge to be applied towards performance outcome. The contextual competencies on the other hand refer to client, the project and environment related skills and knowledge needed to perform on the project. 
A list of PM competencies purely delineated for architects by PM professional bodies is almost non-existent. Kwofie, Adinyira and Botchway (2015) portraying a deep understanding of the tasks, roles, cultural and professional characteristics of the $\mathrm{GCl}$ identified 12 critical PM competencies required by architects for effective and efficient project delivery and task performance in the $\mathrm{GCl}$. The theoretical validity of these competencies by Kwofie, Adinyira and Botchway (2015) is that, they integrate the tenets of the three parameters of PM knowledge and skills towards professional competencies espoused by Omidvar, Samad and Zafarghandi (2011) and most regulatory PM professional bodies. The study further integrated the arguments forwarded by Bothma (2012), Rwelamila (2007), Odusami (2002), EdumFotwe and McCaffer (2000) on the PM skill gaps and requirements of professionals in the construction industry. Further to this, the analytical approach adopted by Kwofie, Adinyira and Botchway (2015) was consistent with similar studies in competency measures and development while the results also showed high level internal consistency, reliability and validity (see Ahadzie et al., 2009; Crawford, 2005; Ling, 2003). Against these backgrounds, the 12 critical PM competencies developed by Kwofie, Adinyira and Botchway (2015) was adopted for this study and is thus summarised in Table 1.

\section{STUDY METHODOLOGY}

Many researches focusing on evaluation of performance behaviours in construction management research have adopted a positivist approach and subsequently used quantitative research design because of its objectivity and the practical reality and reliability (see Omar and Fayek, 2016; Ahadzie et al., 2009; Crawford, 2005; Dainty, Cheng and Moore, 2004). Against this background, this study adopted the positivist paradigm using a quantitative design and subsequently, a questionnaire survey for collecting the empirical data. This stance was chosen to ensure triangulation and theoretical validity with previous studies (cf. Ahadzie et al., 2009; Crawford, 2005; Dainty, Cheng and Moore, 2004). The integrated adopted competencies as summarised in Table 1 was subsequently developed into a questionnaire as the main research instrument. According to Sanchez and Levine (2009), one major issue in performance assessment is to first decide the person who is to determine the criteria as well as form the nucleus of the assessment. Stuckenbruck (1986) revealed that, in PM practice, project managers, project team members, top management and the customer are useful stakeholders in the assessment of performance. Ahadzie, Proverbs and Sarkodie-Poku (2014) and Ahadzie et al. (2009) used similar approach in the $\mathrm{GCl}$ and revealed reliable and valid findings in the identification of PM competencies in mass housing projects with no significant variability in the assessment given by other team members on the project manager's performance. 
Project Management Competencies of Architects

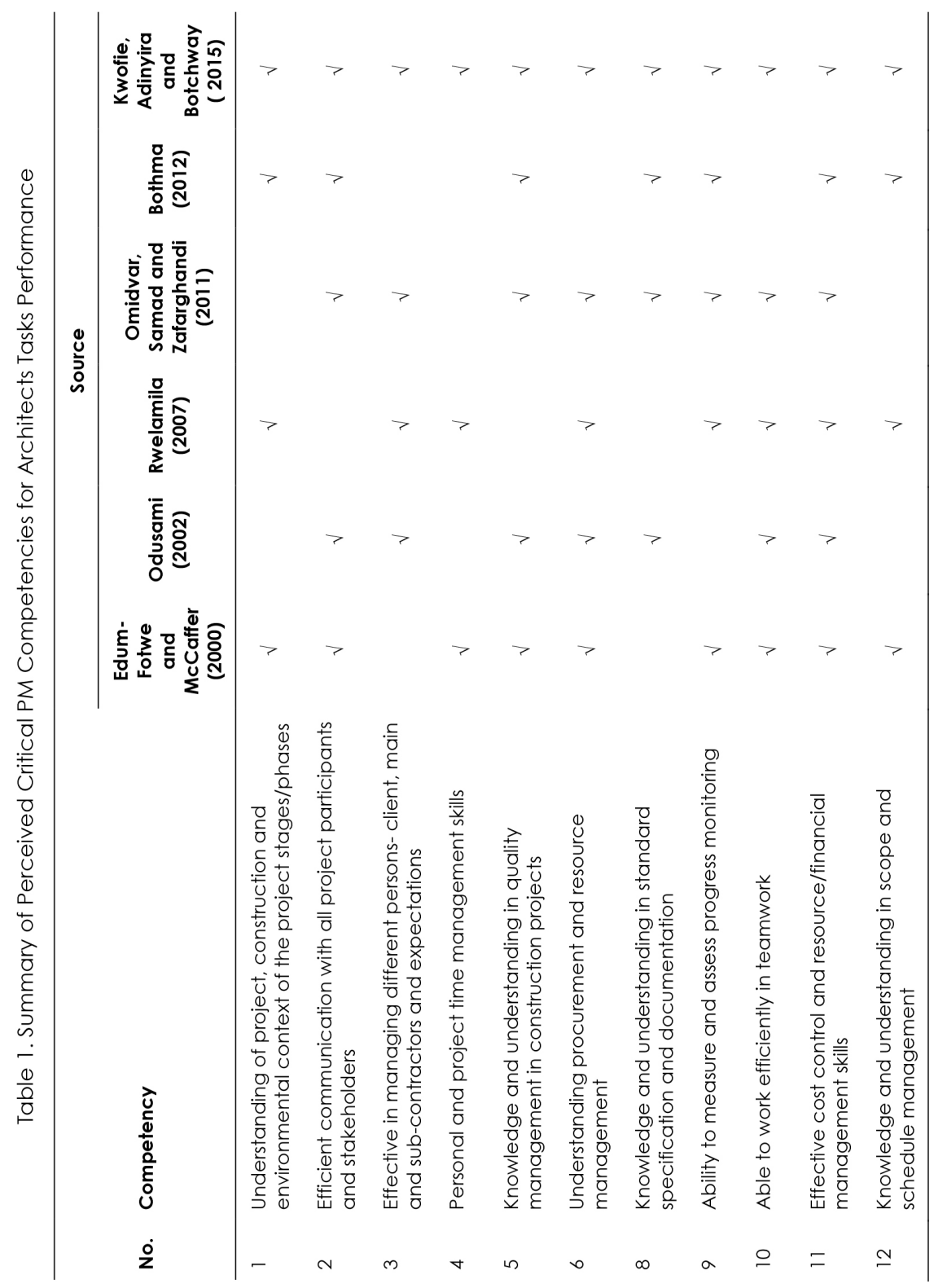


Additionally, in a study by Xiao and Proverbs (2001) and Xiao (2002), the findings revealed that, there was high level consistency in the performance assessment by the other team members on the contractor's performance in project delivery. Generally in mainstream human resource management (HRM) genre, performance assessment and evaluation are theoretically and practically undertaken by superiors, functional managers of similar rank and colleagues in line of duty (Murphy et al., 1982; Olomolaiye and Egbu, 2004). The theoretical perspective of this approach is that, it offers objectivity in the assessment by the assessors having experienced with the one being assessed in the line of duty. This tends to eliminate any bias that is likely to arise if persons assessed their own performance. In the context of this study, practical and theoretical reality indicate that, project team leaders, project team members, client and contractors have consistently been the sampling nucleus in performance measures (see Ahadzie, Proverbs and Sarkodie-Poku, 2014; 2009; Xiao, 2002). Hence in this study, the nucleus of the respondents included project team leaders, quantity surveyors, engineers, clients and the contractors who have worked on construction projects with architects. This is because, they are well placed to draw on their practical experience to offer an objective appraisal of the performance level of architects' PM skills and knowledge. Architects who form part of the project team was not included to eliminate any element of bias in their assessment.

The questionnaire research instrument (RI) was developed into two main sections. Fellows and Liu (2008) revealed that, thorough assessment of the background of respondents is critical in ensuring validity and reliability in a quantitative study. The first section focused on the assessment of the experience, the nature of projects involved in and the professional capacity of the respondents in the project team that worked with the architect. The second section was designed for respondents to assess the expected optimal performance level of each of the PM competencies that are crucial to project success as well as the perceived actual performance level exhibited by the architect on the projects they have been involved in. A conventional five-point Likert scale which have proved very liable in similar studies (see Dainty, Cheng and Moore, 2004; Westerveld, 2003; Ling, 2003) was adopted. In assessing the expected optimal and actual performance level, the five-point Likert scale was interpreted as $1=$ Very low $(0 \%-29 \%) ; 2=$ Low $(30 \%-49 \%)$; $3=$ Average $(50 \%-69 \%) ; 4=$ High $(70 \%-90 \%)$ and $5=$ Very high $(91 \%-100 \%)$. This scale used here was adopted from Xiao (2002) and Ahadzie et al. (2009) which were used in assessing the performance of contractors and project managers respectively in construction project delivery. This adoption is perceived to ensure theoretical validity and triangulation in the performance assessment as it is consistent with mainstream HRM genre (Murphy et al., 1982; Xiao and Proverbs, 2001).

A total of 84 questionnaires were self-administered to project team leaders, team participants (quantity surveyors, engineers (structural, civil, mechanical and electrical engineers), clients and contractors sampled through snowballing in Ghana. This approach was adopted due to the lack of data on such professionals as well as their experience in completed and ongoing projects. These respondents were concentrated in the Greater Accra and Ashanti regions of Ghana. The focus on these two major regions in the data collection was based on the fact that empirically, greater percentages of the built environment professionals and projects are located in Accra and Kumasi (Kwofie, Adinyira and Botchway, 2015; Ahadzie, Proverbs and Sarkodie-Poku, 2014). Mean scores, Kruskal-Wallis Test and gap analysis were employed to analyse and interpret the results. The Kruskal-Wallis Test was done 
to assess the level of agreement of the responses among the various respondents to ensure reliability of the findings. Fundamentally, in the opinion of Stanleigh (2010), level of performance evaluation is the measurement of achievement against optimal expectation. In the context of this study, the evaluation of the performance level is represented as the deviation of the actual performance level (b) from the expected optimal performance level of the competencies by the architect given as $a-b$. Thus, the gap analysis offers a good and valid assessment of a criterion in this context (Ritchey, 2013).

\section{RESULTS AND DISCUSSIONS}

From the 84 questionnaires self-administered in the survey, a total of 54 of the distributed questionnaires were retrieved representing a $64 \%$ response rate.

\section{Respondents Background Information}

The results of the demographic background information on the respondents indicated that, the respondents have had relatively considerable years of experiences in working with architects on construction projects in Ghana. From the total 54 respondents, 89\% (48) had experience above five years. This suggests that, the greater proportion of the respondents exhibit wealth of experience and this is an indication that, they are more likely to know much about the PM inputs of the architects and are thus more likely to offer accurate and truthful judgment on the variables. This is because, practically, in HRM practice in Ghana, a minimum of five years is suitable for employment into senior management position and a person with 10 years of experience is most suitable for executive management position. Similarly, the results suggest that, there is a fairly balanced representation of the professionals and stakeholders that compose the nucleus of performance assessment of the project team on construction projects. From the total 54 respondents, 33\% were project leaders, $24 \%$ were quantity surveyors whereas engineers constituted $11 \%$. A total of $19 \%$ and $13 \%$ represented clients and contractors respectively. The representation by the stakeholders and professionals also offers a balanced judgement on the architect's PM competencies and is thus effective for drawing conclusions and generalisation.

A banded breakdown of the nature of projects the respondents have been involved in from Table 2 above indicates an array of the dominant project typologies (residential, commercial, office, industrial buildings and maintenance work) often encountered in the $\mathrm{GCl}$. By drawing on this, it can be suggested that, the responses offered, more likely reflect the practical perspective of the needed performance of architects on the critical PM competencies across the dominant project typologies in the Ghanaian industry. This situation offers further practical and theoretical credence to the findings of the study. 
Table 2. Background of Respondents in the Survey

\begin{tabular}{lcc}
\hline \multicolumn{1}{c}{ Nature of Projects Involved in } & Frequency & \\
\hline Residential & 25 & \\
Commercial & 15 & \\
Office buildings & 18 & \\
Industrial & 8 & \\
Maintenance & 5 & \\
Total & 71 & 33 \\
Nature of Involvement in Project Teams & Frequency & Percentage \\
Project leaders & 18 & 11 \\
Quantity surveyors & 13 & 19 \\
Engineers (civil, structural, electrical, mechanical/ & 6 & 13 \\
plumbing) & & $100 \%$ \\
Contractors & 10 & Percentage \\
Client & 7 & 11 \\
Total & 54 & 13 \\
Years of Experience of Survey Respondents (Survey) & Frequency \\
0-5 years & 6 & 37 \\
6-10 years & 7 & 39 \\
$11-15$ years & 20 & $100 \%$ \\
16 years and above & 21 & \\
Total & 54 & \\
\hline
\end{tabular}

\section{Level of Agreement among Respondents}

Assessment of level of agreement (inter-rater agreement) in research inquiry testing prior formulations and constructs are well acknowledged for understanding of the consistency in the results and offer credence to the conclusions and generalisations that could be derived (Cohen et al., 2009; Fellows and Liu, 2008; Field, 2005; Harvey and Hollander, 2004). This is because, in any empirical assessment, when decisions on a subject matter or criterion are made on a numerical scale, assessment of interrater agreement are crucial to offer credence and consistency to the results and findings emanating from their judgement by ascertaining that the responses offered are similar and reflecting the degree of "sharedness" among the judges or in the decisions across the various typologies of respondents (Cohen et al., 2009; Fellows and Liu, 2008). In assessing this, notable studies have dominantly used various forms which Kruskal-Wallis tests and Analysis of Variance (ANOVA) are dominantly inclusive. Here, Kruskal-Wallis was used to ascertain the level of agreement in the responses offered on each of the competencies. The choice of the Kruskal-Wallis over other tests such Analysis of Variance (ANOVA) was influenced by the perceived small 
sample size of 54 and the need to avoid violations of normality and homogeneity of variance associated with small sample size using parametric tests such as ANOVA and T-test (see Cohen et al., 2009; Field, 2005; Harvey and Hollander, 2004).

From Table 3, the Kruskal-Wallis test values for all the 12 critical PM competencies were greater than 0.05 and thus interpreted as statistically not significant. This result indicates that, there is generally consistent interpretations and responses from the respondents. Additionally, the standard deviations on the expected and actual performance level given by the respondents were all less than 1.0. A standard deviation (SD) quantifies variability or scatter and thus a value less than 1.0 is an indication that, there is high consistency and low variability in the choice and interpretations of the variables among the respondents (Field, 2005). From this, it can be affirmed without contradiction that, generally, there was high level of agreement among the respondents on their perception of the performance level of theses competencies by the architects towards project success.

It is accounted that, gap analysis is a very useful performance appraisal approach towards improvement (Ritchey, 2013). It is also a way to compare current conditions and practices in performance against the expected level of performance in order to identify gaps and areas in need of improvement (Ritchey, 2013). According to Ritchey (2013) gap analysis aids business organisations and work groups to identify the shortfalls in the expected performance levels against needed optimal performance level and once the performance gaps are determined, the deviation from the expected level is easily known and this may facilitate the process of identifying the necessary steps or actions required to bridge the performance gap. In conducting gap analysis of the performance level of the 12 critical PM competencies of the architects determined (see Table 1), mean scores of the expected performance level of the critical PM competencies were critically compared to the actual performance level exhibited by architects on the projects they have been involved in or engaged on. The results are presented in Table 3. The results were further represented in a web polar chart in Microsoft Excel presented in Figure 1. From the mean scores comparison, seven out of the 12 critical PM competencies determined had their actual performance level below the expected performance level. These were "efficient communication with all project participants and stakeholders", "effective in managing different personsclient, main and sub-contractors and expectations", "personal and project time management skills", "understanding procurement and resource management", "knowledge and understanding in standard specification and documentation", "able to work efficiently in teamwork" and "effective cost control and resource/ financial management skills". 
Table 3. Gap Analysis between the Needed Optimal Performance Level and the Actual Performance by Architects

\begin{tabular}{|c|c|c|c|c|c|c|c|}
\hline \multirow[t]{2}{*}{$\begin{array}{c}\text { Critical PM } \\
\text { Competency }\end{array}$} & \multirow[t]{2}{*}{$N$} & \multicolumn{2}{|c|}{$\begin{array}{l}\text { Needed Optimal } \\
\text { Performance } \\
\text { Impact Level (a) }\end{array}$} & \multicolumn{2}{|c|}{$\begin{array}{c}\text { Actual } \\
\text { Performance } \\
\text { Level of Architects } \\
\text { (b) }\end{array}$} & \multirow[t]{2}{*}{$\begin{array}{c}\text { Gap } \\
\text { Analysis } \\
(a-b)\end{array}$} & \multirow[t]{2}{*}{$\begin{array}{c}\text { Level of } \\
\text { Agreement } \\
\text { (Kruskal-Wallis } \\
\text { Test) }\end{array}$} \\
\hline & & Mean & SD & Mean & SD & & \\
\hline $\begin{array}{l}\text { Understanding } \\
\text { of project, } \\
\text { construction and } \\
\text { environmental } \\
\text { context of the } \\
\text { project stages/ } \\
\text { phases }\end{array}$ & 54 & 4.39 & .685 & 4.56 & .502 & +0.17 & .215 \\
\hline $\begin{array}{l}\text { Efficient } \\
\text { communication } \\
\text { with all project } \\
\text { participants and } \\
\text { stakeholders }\end{array}$ & 54 & 4.41 & .639 & 4.11 & .599 & $-0.30 *$ & .796 \\
\hline $\begin{array}{l}\text { Effective in } \\
\text { managing } \\
\text { different } \\
\text { persons-client, } \\
\text { main and sub- } \\
\text { contractors and } \\
\text { expectations }\end{array}$ & 54 & 4.46 & .539 & 3.96 & .726 & $-0.5^{*}$ & .325 \\
\hline $\begin{array}{l}\text { Personal and } \\
\text { project time } \\
\text { management } \\
\text { skills }\end{array}$ & 54 & 4.43 & .602 & 3.22 & .965 & $-1.21^{*}$ & .462 \\
\hline $\begin{array}{l}\text { Knowledge and } \\
\text { understanding } \\
\text { in quality } \\
\text { management } \\
\text { in construction } \\
\text { projects }\end{array}$ & 54 & 4.37 & .653 & 4.63 & .592 & +0.26 & .068 \\
\hline $\begin{array}{l}\text { Understanding } \\
\text { procurement } \\
\text { and resource } \\
\text { management }\end{array}$ & 54 & 4.20 & .655 & 3.85 & .810 & $-0.35^{*}$ & .061 \\
\hline $\begin{array}{l}\text { Knowledge and } \\
\text { understanding } \\
\text { in standard } \\
\text { specification and } \\
\text { documentation }\end{array}$ & 54 & 4.48 & .540 & 3.46 & .693 & $-1.02^{*}$ & .131 \\
\hline $\begin{array}{l}\text { Ability to } \\
\text { measure and } \\
\text { assess progress } \\
\text { monitoring }\end{array}$ & 54 & 4.50 & .505 & 4.67 & .476 & +0.17 & .162 \\
\hline
\end{tabular}


Table 3. (continued)

\begin{tabular}{|c|c|c|c|c|c|c|c|}
\hline \multirow[t]{2}{*}{$\begin{array}{l}\text { Critical PM } \\
\text { Competency }\end{array}$} & \multirow[t]{2}{*}{$N$} & \multicolumn{2}{|c|}{$\begin{array}{l}\text { Needed Optimal } \\
\text { Performance } \\
\text { Impact Level (a) }\end{array}$} & \multicolumn{2}{|c|}{$\begin{array}{c}\text { Actual } \\
\text { Performance } \\
\text { Level of Architects } \\
\text { (b) }\end{array}$} & \multirow[t]{2}{*}{$\begin{array}{l}\text { Gap } \\
\text { Analysis } \\
(a-b)\end{array}$} & \multirow[t]{2}{*}{$\begin{array}{c}\text { Level of } \\
\text { Agreement } \\
\text { (Kruskal-Wallis } \\
\text { Test) }\end{array}$} \\
\hline & & Mean & SD & Mean & $S D$ & & \\
\hline $\begin{array}{l}\text { Able to work } \\
\text { efficiently in } \\
\text { teamwork }\end{array}$ & 54 & 4.26 & .556 & 2.76 & .989 & $-1.5^{*}$ & .212 \\
\hline $\begin{array}{l}\text { Effective cost } \\
\text { control and } \\
\text { resource/ } \\
\text { financial } \\
\text { management } \\
\text { skills }\end{array}$ & 54 & 4.46 & .503 & 2.61 & .998 & $-1.85^{*}$ & .396 \\
\hline $\begin{array}{l}\text { Knowledge and } \\
\text { understanding } \\
\text { in scope and } \\
\text { schedule } \\
\text { management }\end{array}$ & 54 & 4.24 & .512 & 4.48 & .596 & +0.24 & .696 \\
\hline $\begin{array}{l}\text { Uphold high } \\
\text { ethical practice } \\
\text { and professional } \\
\text { conduct }\end{array}$ & 54 & 4.13 & .972 & 4.61 & .596 & +0.48 & .062 \\
\hline
\end{tabular}

Note: *Actual performance level of architects on the variable below the expected performance level.

\section{Results of Gap Analysis}

This is effectively depicted in the polar chart in Figure 1. From the chart, the series 1 represented the expected performance level of architects on these PM competencies whilst the series 2 depicted the actual performance level of architects. It clearly shows that, seven of the PM competencies identified above fall below the expected performance level (series 1) needed to influence project success indicating a gap or deficiency in their performance level. 


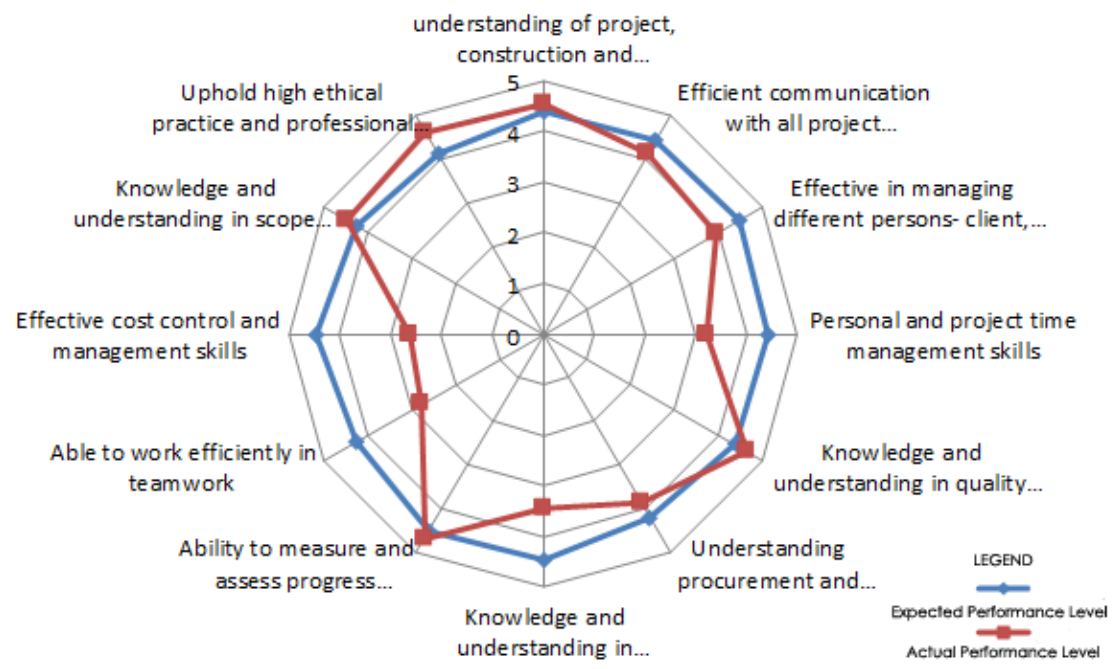

Figure 1. Polar Chart of the Gap Analysis

\section{Discussion of Results}

The empirical data gathered have identified the performance levels of the 12 critical PM competencies by architects. From the results, architects showed performance level in five PM competencies that are above the needed optimal performance and below the acceptable performance in seven of the competencies. The following discussions are structured to focus on the seven competencies that fall short of the expected performance level needed towards project success in the Ghanaian construction industry.

\section{Efficient communication with all project participants and stakeholders}

It was gathered from the construction practitioners that, performance level of Architects on this skill falls short of the expected level needed to trigger the necessary project success on projects they are engaged on. Effective communication among project teams and stakeholders have persistently been cited as a crucial factor towards successful organisations as well as project delivery success (Forman and Argenti, 2005; Gorse and Emmitt, 2007; Dainty, Murray and Moore, 2006). However, Foreman and Argenti (2005) revealed that, many practitioners in the industry perceive internal and external communication as a very challenging task function. Generally, communication task function forms about $90 \%$ of the tasks performed by construction team participants and thus developing effective task and contextual communication skills is crucial in towards engendering effective communication outcome (Gorse and Emmitt, 2007; Dainty, Murray and Moore, 2006). Practically in the context of the Ghanaian construction industry, Fugar and Agyakwah-Baah (2010) identified, poor communication as a major factor that causes project delays due to late response to change request, drawing update and discrepancies in designs. It can be said that, traditionally, given the highlight by Fugar and Agyakwah-Baah 
(2010), architects remain central in ameliorating such developments. Against this, it is important for architects to strive towards effective communication by developing key communication tasks functional skills which are the key in ensuring good design management practices, effective and complete designs as well as quick response to needed information. Xia et al. (2015) revealed that project definition and clarity significantly affects the quality of communication among project stakeholders. In the light of this, it is important for architects to further deepen their skills on project definition to enhance the clarity of communication in project delivery.

\section{Effective in managing different persons-client, main and sub-contractors and expectations}

The adversarial nature of the construction project environment coupled with competing expectations of stakeholders which includes clients, contractors and sub-contractors (Orgen et al., 2012; Azmy, 2012) requires sound management approach and strategies to successfully navigate the various phases of the project life-cycle to deliver project success and client satisfaction. Practically, in the Ghanaian construction industry, issues of trust, mutual respect and power struggle have been major causes of team breakdown and conflicts among the clients, contractors and sub-contractor (Orgen et al., 2012). In the traditional role of Architects as team leaders in the industry, they are expected to manage control and build trust, respect and confidence among the client, contractor and subcontractor by being fair, honest and impartial to engender sound environment for the smooth delivery of construction projects. However, given the poor performance on the above competency, it can be said that this is an evidence of worrying signs for the industry as can enormously contribute to the already existing adversarial nature of the industry.

Against this, it is of dire importance that, architects as project leaders continue through continuous professional development to develop new skills and enhance existing ones aimed at ameliorating the existing tensions among clients and contractors by enhancing client-contractor and contractor-sub-contractor relationships. This will in no doubt help in improving performance in construction project delivery in Ghana.

\section{Personal and project time management skills}

Project delays and time overruns have become a common feature of the Ghanaian construction industry (Buertey, Miezah and Adjei-Kumi, 2013). It is no surprising of the poor performance level of this competency among architects. Ahadzie et al. (2009) revealed the relevance of project success especially in relation to delivering projects on time and on budget to clients in the Ghanaian construction industry across all project typologies. Practically, it has become a common habit among professional architects to constantly, postponed meetings, make late decisions on project and site issues and undertake frequent variation orders which are often not requested by the client which not in doubt can significantly give impact on the progress of the project as well as causing delays. Again, poor supervision by architects has also become common in the industry and thus conscious and practical efforts are needed to improve time and progress management performance on projects. 


\section{Understanding procurement and resource management}

Sound knowledge and understanding of effective procurement management and route are perceived as central to the objective selection of competent, credible and high performing contractors for a construction projects (Gray and Hughes, 2012). It is further posited that the success of any adopted procurement management approach strongly depends on the practical and contextual characteristics of any given industry. From a practical and theoretical understanding of the industry in Ghana, architects play a major role in the procurement and resource management in the delivery of construction projects. Hence, the poor performance on this crucial skill can be perceived as a worrying sign for the industry. Kwofie, Adinyira and Botchway (2015) revealed that, many professional architects lack clear understanding and knowledge on the public procurement regulations that controls public procurement in Ghana. A plausible explanation to this is that the regulation though was passed in year 2003, it is yet to be integrated into the professional training of architects in most institutions training architects in Ghana. This notwithstanding, given the role of architects in the industry, there is the need for continuous professional development on procurement practices peculiar to the Ghanaian context to engender expected performance outcome among architects towards success.

\section{Knowledge and understanding in standard specification and documentation}

Frequent change orders have remained a common feature of the global construction industry and the major factor attributed to this development frequent design errors, specification discrepancies, inconsistencies in the changes in designer preferences (Civitello, 2002). Civitello (2002) however contend that, a reduction to the barest minimum of these happening is crucial if a sustained success and acceptable performance in the delivery of construction projects is desired by practitioners, clients and stakeholders. Love and Li (2000) revealed that, as much as over $60 \%$ of rework on construction projects originate from poor and inaccurate designs and discrepancies in specification. This statement suggests that, ensuring efficient design and effective design management is crucial to meeting project goals and client satisfaction. Against this background, it can be said that the poor performance by architects on the competency cannot continue to persist if improvement in success and project performance is to be registered in the Ghanaian construction industry. Hence, architects must lead the way and assume full control in ensuring that complete design drawings and documentation that forms the basis of both cost and engineering analysis are always given throughout the various phases of the project life cycle when required. Given that design management is a critical PM function that can be seen as a sine qua non for project performance and effective communication (Xia et al., 2015), it stands to reason that architects performance in this is non-negotiable. Hence architects must pursue all skills needed to effectively perform in their design functions and tasks in project delivery.

\section{Ability to work efficiently in teams}

Extant literature have continuously suggested effective skills in managing teams as critical to ensure effectiveness of the team which is a sine qua non for team 
performance (Baiden, Price and Dainty, 2006; Azmy, 2012). Team base approach to construction project delivery has gained credence as a viable approach that has a propensity to trigger enhanced performance outcome over the traditional individual methods (Dainty, Murray and Moore, 2006; Azmy, 2012). In spite of this recognition and the practical evidence of use of team base approach in the Ghanaian construction industry, architects performance on this competency fell short of the expected level. It can be suggested that, even though the team based approach is dominant in the construction industry in Ghana, there are evidence of continuous discord, disagreement and entrenched positions which are likely due to strong attachment of the professionals to their professions than the goals of the projects. Practically, though Architects often traditionally play the role of team leaders, they also assume parallel functional role with project managers in PM approach and sometimes do not accept instructions from project managers (Orgen et al., 2012). In the opinion of Blodgett, Bakir and Rose (2008), these developments are expected where professionals in hierarchical positions take entrenched position and often do not accept equality in decision making and power as a result of high power distance index.

It can be said that, team approach has become the dominant going method in project delivery and thus given the suitability of Architects for leadership and sometimes project manager role, it is very important for them to continuously develop skills, attitudes and emotions that are central to curtailing the perceived adversarial project environment often encountered in the industry. Architects must also develop cordial approach that can significantly manage the expectations of clients and task functions of team participants, contractors and sub-contractors to meet project goals.

\section{Effective cost control and resource/financial management skills}

A study by Dogbegah, Owusu-Manu and Omoteso (2011) emphasised that knowledge in financial resource and cost management is very critical to all project team participants in the Ghanaian construction industry. Cost overrun, shortage of materials on projects, use of obsolete equipment remains an endemic problem in the industry in Ghana. However, it is a common knowledge that architects have often been criticised for not making their designs and decisions so commensurate to the "pocket" of their clients. There is enough evidence that further suggests that architects acting as team leaders have been criticised for not offering enough advise to contractors to properly manage their resources and site to ensure efficient and regular supply of materials on the projects when payment have been made on the works to the contractor. Besides, these criticisms are also fueled by the frequent variations due to incomplete working drawings leading to surge in cost. Fugar and Agarkwa-Baah (2010) lamented that underestimation of project cost is prevalent in the industry and is also ranked very high as a major factor influencing project delays due to cost overrun. From Figure 1, it is seen that this competency emerged as the worst performed by architects in the industry. Given that delivering projects on cost still remains high from literature as a critical success criteria in the global construction industry as well as a sign of the performance of the industry and the project team (Westerveld, 2003; Crawford, 2005), it is primarily critical for architects to develop and sharpen this skill.

It is worth nothing also that, the performance of architects in these five competencies: (1) understanding of project, construction and environmental 
context of the project stages/phases, (2) knowledge and understanding in quality management in construction projects, (3) ability to measure and assess progress monitoring, (4) knowledge and understanding in scope and schedule management and (5) uphold high ethical practice and professional conduct, were adjudged to be acceptable. Drawing on this, it can be affirmed that, it is very important for practitioners to understand that, the relevance of quality management issues, scope and schedule management and ethical issues in PM practice remain crucial in stimulating success as well as client satisfactions (Shen and Liu, 2003; Chan, Scott and Chan, 2004; Alias et al., 2014). Against this background, it can be said that though the performance on these five competencies were acceptable, it is important for architects to continue to develop and perform on these skills to influence the needed success in construction project delivery in the construction industry.

\section{CONCLUSIONS AND RECOMMENDATIONS}

The study has sought to determine the performance level of PM competencies that are critical to architects' role in project delivery. It also revealed that architects show poor performance on seven of the critical PM skills. There is an understanding that, PM skills are crucial not only for the project manager but to all project team participants such as the architect in order to contribute significantly in his role towards project success. There is further evidence form the study that suggests that, improvement in these skills on the part of the architect is eminent to achieving success on construction project delivery. It must thus be emphasised that a clear understanding of these skills and related improvement is thus needed in the training and practice of architects. The findings suggested that, from the perspective of the stakeholders and building professionals in the Ghanaian construction industry, the architects' performance in "efficient communication with all project participants and stakeholders", "effective in managing different persons-client, main and sub-contractors and expectations", "personal and project time management skills", "understanding procurement and resource management", "knowledge and understanding in standard specification and documentation", "able to work efficiently in teamwork" and "effective cost control and resource/financial management skills" were below the expected level likely to trigger the needed success on projects.

The greatest challenge to effective PM practice and the application of its sound tools and techniques in the Ghanaian construction industry is due to lack of capable human resource. Against this, a very significant recommendation emanating from the findings is the need for practicing architects to undertake continuous development on their knowledge and skills in PM practices. Dwelling on the results from the study, it fits to say that the deficiencies relating to these identified PM skills could be attributed to gaps in the training of architects in the educational institutions in Ghana. The findings provide all stakeholders a clear understanding of the deficiencies in PM skills and knowledge. This should however enable training institutions to align and orientate their curriculum to include PM knowledge and skills in the training of architects' management requirement towards practice in Ghana. Also the argument over who is better qualified and positioned to be effective project manager in a project team rages on in many academic scholarships. Drawing on this above, these findings become a resource for architects to align their professional development towards improving their skills on these competencies towards a stable 
career in PM necessary to meeting the managerial challenges and ameliorating the inefficiencies in the Ghanaian construction industry.

However, given that different performance levels is likely to happen at the various phases of project life cycle, further studies are recommended focusing on the various phases to aid in longitudinal and strategic PM delivery across these project phases to maximise performance outcome among architects.

\section{REFERENCES}

Adams, J.R. and Thomas, M. (1991). Integrating strategic project management. PM Network, 5(8): 37-40.

Ahadzie, D.K. and Amoa-Mensa, K. (2010). Management practices in Ghanaian house building industry. Journal of Science and Technology, 30(2): 62-75. https://doi.org/10.4314/just.v30i2.60533.

Ahadzie, D.K., Proverbs, D. and Sarkodie-Poku, I. (2014). Competencies required of project managers at the design phase of mass housing building projects. International Journal of Project Management, 32(6): 958-969. https://doi. org/10.1016/j.ijproman.2013.10.015.

Ahadzie, D.K., Proverbs, D.G., Olomolaiye, P.O. and Ankrah, N.A. (2009). Competencies required by project managers for housing construction in Ghana Implications for CPD agenda. Engineering, Construction and Architectural Management, 16(4): 353-375. https://doi. org/10.1108/09699980910970842.

Alias, Z., Zawawi, E.M.A., Yusof, K. and Aris, N.M. (2014). Determining critical success factors of project management practice: A conceptual framework. Procedia-Social and Behavioral Sciences, 153: 61-69. https://doi.org/10.1016/j.sbspro.2014.10.041.

Azmy, N. (2012). The role of team effectiveness in construction project teams and project performance. PhD diss. lowa State University Ames.

Baiden, B.K., Price, A.D.F. and Dainty, A.R.J. (2006). The extent of team integration within construction projects. International Journal of Project Management, 24(1): 13-23. https://doi.org/10.1016/j.jpproman.2005.05.001.

Blodgett, J.G., Bakir, A. and Rose, G.M. (2008). A test of the validity of Hofstede's cultural framework. Journal of Consumer Marketing, 25(6): 339-349. https:// doi.org/10.1108/07363760810902477.

Bothma, S.F. (2012). Developing project management competencies in graduate engineers in the construction industry. MBA diss. University of Pretoria.

Brown, K. (2000). Developing project management skills: A service learning approach. Project Management Journal, 31(4): 53-58. https://doi. org/10.1177/875697280003100408.

Buertey, J.L.T., Miezah, A.K. and Adjei-Kumi, T. (2013). Delays to large construction projects in Ghana: A risk overview. In S. Laryea and S. Agyepong (eds.). Proceedings: 5th West Africa Built Environment Research (WABER) Conference. Accra, Ghana: WABER Conference, 367-380.

Chan, A.P.C., Scott, D. and Chan, A.P.L. (2004). Factors affecting the success of a construction project. Journal of Construction Engineering Management, 130(1): 153-155. https://doi.org/10.1061/(ASCE)0733-9364(2004)130:1 (153). 
Chinowsky, P., Diekman, J. and Galoti, V. (2008). Social network model of construction. Journal of Construction Engineering and Management, 134(10): 804-812. https://doi.org/10.1061/(ASCE)0733-9364(2008)134:10(804).

Civitello, M.A. (2002). Contractors Guide to Change Orders. 2nd Ed. Upper Saddle River, NJ: Prentice Hall Inc.

Cohen, A., Doveh, E. and Nahum-Shani, I. (2009). Testing agreement for multi-item scales with the indices $r_{W G(J)}$ and $A D_{M(J)}$. Organizational Research Methods, 12(1): 148-164. https://doi.org/10.1177/1094428107300365.

Crawford, L. (2005). Senior management perceptions of project management competence. International Journal of Project Management, 23(1): 7-16. https://doi.org/10.1016/j.jproman.2004.06.005.

. (1998). Project management competence for strategy realisation. In A. Hauc, R. Kovac, B. Rozman, A. Semolic and A. Skarabot (eds.). Proceedings: 14th World Congress on Project Management. Ljubljana, Slovenia: International Project Management Association and Slovenian Project Management Association, 10-21.

Dainty, A., Murray, M. and Moore, D. (2006). Communication in Construction: Theory and Practice. London: Taylor and Francis. https://doi. org/10.4324/9780203358641.

Dainty, A.R.J., Cheng, M.I. and Moore, D.R. (2004). A competency-based performance model for construction project managers. Construction Management and Economics, 22(8): 877-886. https://doi.org/10.1080/01446 19042000202726.

Danso, A.K. and Fugar, F.D.K. (2009). Capacity-building in construction administration: Key to effective utlisation of the district assembly common Fund for infrastructural development. Journal of the Ghanaian Surveyor, 2(1): $1-5$.

Dogbegah, R., Owusu-Manu, D. and Omoteso, K. (2011). A principal component analysis of project management competencies for the Ghanaian construction industry. Australasian Journal of Construction Economics and Building, 11 (1): 26-40. https://doi.org/10.5130/ajceb.v11i1.1680.

Draganidis, F., Chamopoulou, P. and Mentzas, G. (2006). An ontology based tool for competency management and learning paths. Paper presented at the I-KNOW, Graz, Austria.

Edum-Fotwe, F.T. and McCaffer, R. (2000). Developing project management competencies: Perspectives from the industry. International Journal of Project Management, 18(2): 111 -124. https://doi.org/10.1016/S0263-7863(98)90075-8.

Enshassi, A., Mohamed, S. and Abushaban, S. (2009). Factors affecting the performance of construction projects in the Gaza Strip. Journal of Civil Engineering and Management, 15(3): 269-280. https://doi.org/10.3846/13923730.2009.15.269-280.

Fayek, A.R. (2012). Advancing fuzzy hybrid techniques for competency modeling of construction organizations. Paper presented at the NSERC Discovery Grant Application 2013-2017. University of Alberta, Edmonton, Canada.

Fellows, R. and Liu, A. (2008). Research Methods for Construction. West Sussex, UK: Blackwell Pubishing.

Field, A. (2005). Discovering Statistics Using SPSS for Windows. London: Sage Publications. 
Foreman, J. and Argenti, P.A. (2005). How corporate communication influences strategy implementation, reputation and the corporate brand: An exploratory qualitative study. Corporate Reputation Review, 8(3): 245-264. https://doi. org/10.1057/palgrave.crr.1540253.

Fugar, F.D.K. and Agyakwah-Baah, A.B. (2010). Delays in building construction projects in Ghana. Australasian Journal of Construction Economics and Building, 10(1/2): 103-116. https://doi.org/10.5130/ajceb.v10i1/2.1592.

Gillies, A. and Harris, D. (2009). Performance improvement in a community care setting in Canada. Proceedings of the 4th European Conference on Entrepreneurship and Innovation. Antwerp, Belgium: Academic Conferences Ltd.

Gorse, C.A. and Emmitt, S. (2007). Communication behaviour during management and design team meetings: A comparison of group interaction. Construction Management and Economics, 25(11): 1197-1213. https://doi. org/10.1080/01446190701567413.

Gray, C. and Hughes, W. (2012). Building Design Management. Oxford: ButterworthHeinemann.

Harvey, R.J. and Hollander, E. (2004). Benchmarking $r_{w G}$ interrater agreement indices: Let's drop the .70 rule-of-thumb. Paper presented at the 19th Annual Conference of the Society for Industrial and Organisational Psychology. Chicago, Illinois, 24 April.

Koskela, L., Huovila, P. and Leinonen, J. (2002). Design management in building construction: From theory to practice. Journal of Construction Research, 3(1): 1-16. https://doi.org/10.1142/S1609945102000035.

Kwofie, T.E., Adinyira, E. and Botchway, E.A. (2015). Identification of the critical project management competencies of architects in the Ghanaian construction industry. International Journal of Construction Management, 15(4): 288-298. https://doi.org/10.1080/15623599.2015.1067347.

Ling, Y.Y. (2003). A conceptual model for selection of architects by project managers in Singapore. International Journal of Project Management, 21 (2): 135-144. https://doi.org/10.1016/S0263-7863(02)00014-5.

Love, P.E.D. and Li, H. (2000). Quantifying the causes and costs of rework in construction. Construction Management and Economics Journal, 18(4): 479490. https://doi.org/10.1080/01446190050024897.

Masrom, M.A., Skitmore, M. and Bridge, A. (2013). Determinants of contractor satisfaction. Construction Management and Economics, $31(7)$ : 761-779. https://doi.org/10.1080/01446193.2013.814919.

Murphy, K.R., Garcia, M., Kerkar, S., Martin, C. and Balzer, K. (1982). Relationship between observational accuracy and accuracy in evaluating performance. Journal of Applied Psychology, 67(3): 320-325. https://doi.org/10.1037/00219010.67.3.320.

Odusami, K.T. (2002). Perceptions of construction professionals concerning important skills of effective project leaders. Journal of Management in Engineering, 18(2): 61-67. https://doi.org/10.1061/(ASCE)0742-597X(2002)18:2(61).

Odusami, K.T. and lyagba, R.R. (2001). The most suitable professional for team leadership on building projects as perceived by the professionals in the construction industry. Professional Builder, July: 64-73.

Ogunsemi, D.R., Oyediran, O.S. and Ekundayo, D.O. (2008). Construction professionals and project management competencies in Nigeria. Journal of Construction, 1(2): 6-11. 
Olomolaiye, A. and Egbu, C. (2004). The significance of human resource issues in knowledge management within the construction industry: People, problems and possibilities. In F. Khosrowshahi (ed.). Proceedings of the 20th Annual ARCOM Conference. Edinburgh, UK: Heriot-Watt University, 533-540

Omar, M.N. and Fayek, A.R. (2016). Organizational competencies and project performance tool (OCPPT): Evaluating construction project competencies and performance. International Journal of Architecture, Engineering and Construction, 5(1): 29-43.

Omidvar, G., Samad, Z.B.A. and Zafarghandi, S.F. (2011). Critical evaluation of project manager's competency standards for proposing a comprehensive model. Paper presented at the ler Congrès International en Management et Gestion des Projets. Gatineau (Québec), Canada.

Orgen, N.K., Ahadzie, D.K., Ayarkwa, J. and Badu, E. (2012). An integrated supply chain relationship management theoretical framework for improving Engineering and Design Service Delivery (EDSD) to building contractors in Ghana. In S. Laryea, S.A. Agyepong, R. Leiringer and W. Hughes (eds.). Proceedings: 4th West Africa Built Environment Research (WABER) Conference. Abuja, Nigeria: WABER Conference, 1-7.

Oyedele, L.O., Tham, K.W., Jaiyeoba, B.E. and Fadeyi, M.O. (2003). Model for predicting architect's performance in building delivery process. Journal of Engineering, Design and Technology, 1(2): 168-186. https://doi.org/10.1108/ eb060896.

Pellegrinelli, S. and Bowman, C. (1994). Implementing strategy through projects. Long Range Planning, 27(4): 125-132. https://doi.org/10.1016/0024-6301(94)900620 .

Project Management Institute (PMI) (2008). A Guide to the Project Management Body of Knowledge. 3rd Ed. Pennsylvania: PMI.

Ritchey, T. (2013). Morphological gap analysis using GMA to find the change. Acta Morphologica Generalis, 2(2): 1-14.

Rwelamila, P.M. (2007). Construction project management education programmes in South Africa: Addressing the gap. Paper presented at the Second International Conference World of Construction Project Management. Delft, The Netherlands, 24-26 October.

Sanchez, J.I. and Levine, E.L. (2009). What is (or should be) the difference between competency modelling and traditional job analysis? Human Resource Management Review, 19(2):53-63. https://doi.org/10.1016/j.hrmr.2008.10.002.

Shen, Q. and Liu, G. (2003). Critical success factors for value management studies in construction. Journal of Construction Engineering and Management, 129(5): 485-491. https://doi.org/10.1061/(ASCE)0733-9364(2003) 129:5(485).

Skipper, C.O. and Bell, L.C. (2008). Leadership development and succession planning. Leadership and Management in Engineering, 8(2): 77-84. https:// doi.org/10.1061/(ASCE) 1532-6748(2008)8:2(77).

Stanleigh, M. (2010). Use Competency Assessments to Close Project Management Skill Gaps. Toronto: Business Improvement Architects. Available at: http:// www.bia.ca/articles/use-competency-assessments-to-close-projectmanagement-skill-gaps/ [Accessed on 20 November 2013].

Stuckenbruck, L.C. (1986). Who determines project success? Proceedings of the 18th Annual Seminar/Symposium (Montreal/Canada). Upper Darby, PA: Project Management Institute, 85-93. 
Westerveld, E. (2003). The project excellence model: Lining success criteria and critical success factors. International Journal of Project Management, 21 (6): 411-418. https://doi.org/10.1016/S0263-7863(02)00112-6.

Xia, B., Xiong, B., Skitmore, M., Wu, P. and Hu, F. (2015). Investigating the impact of project definition clarity on project performance: Structural equation modelling study. Journal of Management in Engineering, 32(1): 1061-1070.

Xiao, H. (2002). A comparative study of constractor performance based on Japanese, UK and US Construction practice. PhD diss. University of Wolverhampton.

Xiao, H. and Proverbs, D. (2001). A comparison of contractor performance in Japan, the UK and the US: Some preliminary findings from a new approach. In A. Akintoye (ed.). Proceedings: 17th Annual ARCOM Conference. Vol. 1. Salford, UK: Association of Researchers in Construction Management, 661-669.

Xiong, B., Skitmore, M., Xia, B., Masrom, M.A., Ye, K. and Bridge, A. (2013). Examining the influence of participant performance factors on contractor satisfaction: A structural equation model. International Journal of Project Management, 32(3): 482-491. https://doi.org/10.1016/j.ijproman.2013.06.003.

Yadollahi, M., Mirghasemi, M., Zin, R. and Singh, B. (2014). Architect critical challenges as a project manager in construction projects: A case study. Advances in Civil Engineering, 2014: 1-15. https://doi.org/10.1155/2014/205310.

Zavadskas, E.K., Turskis, Z. Tamosaitiene, J. and Marina, V. (2008). Selection of construction project managers by applying Copras- $G$ method. Computer Modelling and New Technologies, 12(3): 22-28. 